\title{
Coping with globalization: Asian versus Latin American strategies of development, 1980-2010
}

\author{
ATUL KOHLI*
}

When compared to Latin America, Asian economies since 1980 have grown faster and have done so with relatively modest inequalities. Why? A comparison of Asia and Latin America underlines the superiority of the nationalist capitalist model of development, which has often been pursued more explicitly in Asia, over that of a dependent capitalist model, which has often been pursued in Latin America. In comparison to Latin America, the Asian model has facilitated higher and less volatile rates of economic growth and a greater political room to pursue social democratic policies. The "tap root" of these alternate pathways is relative autonomy from global constraints: states and economies in Asia have been more nationalist and autonomous than in Latin America.

Keywords: capitalist development; Washington consensus; economic performance.

JEL Classification: P51; 057.

How integrated developing countries should be with the global political economy has again emerged as an issue for debate. The major point of debate is whether the integration should be full or selective and, if selective, on what dimensions. Even in the heyday of dependency theory during the 1960s and the 1970s, autarky was considered an extreme position; sophisticated analysts argued instead for "selective and strategic integration" with the global economy. ${ }^{1}$ Over the next few

\footnotetext{
* Princeton University. E-mail: kohli@princeton.edu.This is a modified and updated version of a paper that was published in December 2009 as a part of a festschrift for Fernando Henrique Cardoso in Studies in Comparative International Development. Submitted: 29/July/2011; Approved: $8 /$ November/2011.

${ }^{1}$ See, for example, the essays in Fishlow (1978), especially the essay by the late Carlos Diaz-Alejandro.
} 
decades this call for partial integration was drowned by the emergence of the so called "Washington Consensus" on development, which championed open economies and full (or near full) integration of developing countries. A variety of pressures have by now shattered this consensus too, including: how poor economic performance of intervening years has been interpreted; a number of global financial crises; and the emergence of democratic regimes in many developing countries, especially in Latin America, whose priorities go beyond paying off foreign debt. Over the last decade then, a number of important countries have quietly moved away from the more strict forms of neo-liberal development model, so much so that a worried Economist in a recent issue (January 21-27,2012) ran a cover story entitled, "the rise of state capitalism," with a focus on Brazil, China and Russia. The scholarly and policy issue now is: what next? As a variety of individual developing countries grope for their own pathways — as they must - are any broad lessons available from recent development experiences?

In this essay I compare the recent development experiences of Asian and Latin American countries with the hope of deriving some general lessons. My focus below is of course on how the countries of these two regions have negotiated their respective links with the global economy over the last three decades. While respecting the internal diversities within Asia and Latin America, I characterize below the model of development pursued in Asia as nationalist capitalist and that in Latin America as dependent capitalist. The comparison of these two broadly distinguishable models of development underlines the superiority of the nationalist capitalist model of development, which has often been pursued more explicitly in Asia, over a dependent capitalist model, which has often been pursued in Latin America. In comparison to Latin America, the Asian model has facilitated higher and less volatile rates of economic growth, and a greater political room to pursue social democratic policies. The "tap root" of these alternate pathways, however, is not only relative levels of economic dependency, but also of political dependency; the real "tap root" then is alternate state types, more nationalist and developmentally effective in Asia, and more neo-liberal and complicit with global capital in Latin America.

The essay proceeds as follows. I first paint in broad brush strokes the pattern of development in select Asian cases that best exemplify a nationalist capitalist model, juxtaposing them to select Latin American cases of more dependent development. I then try to explain these contrasting pathways by emphasizing their political origins. Finally, I point to the main alternative pathways available to developing countries in a globalized world, selective integration under the leadership of nationalist states, or dependent development. As a caveat at the outset, it is important to note that, in what follows, I do not pretend to provide anything close to a comprehensive analysis of a cross-regional comparison of Asia and Latin America. The more modest aim is to highlight how states in Asian and Latin American countries have coped with globalization, with distinct outcomes. 
Both Asia and Latin America are, of course, big places with enormous internal diversity; economic performance in these regions has also varied over time. And yet, depending on the level of abstraction, the two regions can also be viewed as typifying alternate developmental pathways, especially since the 1980s, when Latin America embraced the "Washington consensus" on development more ardently than did most Asian countries. Some basic data on growth and inequality in the important countries of the two regions are presented in Table 1. While growth and inequality are not the only desirable components of "development," they are core values, especially because rapid growth with modest inequalities helps the poor. The data in Table 1 (also depicted in bar graphs in Figures 1 and 2) only confirm what is well known, namely, that when compared to Latin America, Asian economies have grown faster and have done so with relatively modest inequalities.

Table 1: Growth and Inequality*

\begin{tabular}{|c|c|c|c|c|}
\hline \multicolumn{5}{|c|}{ Annual GDP Growth (\%) Income Inequality } \\
\hline Latin America & $1965-1980$ & $1980-2010$ & $1990-2010$ & $\begin{array}{l}\text { (ratio, top } 20 \% \\
\text { to bottom } 20 \% \text { ) }\end{array}$ \\
\hline Argentina & 3.4 & 2.6 & 4.4 & 12.5 \\
\hline Bolivia & 4.4 & 2.5 & 3.9 & 20.3 \\
\hline Brazil & 9.0 & 2.9 & 3.1 & 19.3 \\
\hline Chile & 1.9 & 4.2 & 5.2 & 14.3 \\
\hline Colombia & 5.7 & 3.4 & 3.4 & 20.7 \\
\hline Ecuador & 6.3 & 2.8 & 3.1 & 13.5 \\
\hline Mexico & 6.5 & 2.0 & 2.4 & 14.0 \\
\hline Peru & 3.9 & 2.9 & 4.5 & 13.3 \\
\hline Venezuela & 3.7 & 1.7 & 2.1 & 9.8 \\
\hline Average & 5.0 & 28 & 36 & 153 \\
\hline Asia & $1965-1980$ & $1980-2010$ & $1990-2010$ & $\begin{array}{l}\text { (ratio, top } 20 \% \\
\text { to bottom } 20 \% \text { ) }\end{array}$ \\
\hline Bangladesh & - & 4.7 & 5.3 & 4.6 \\
\hline China & 7.3 & 10.4 & 10.5 & 8.0 \\
\hline India & 3.0 & 6.5 & 6.8 & 5.6 \\
\hline Indonesia & 7.0 & 5.2 & 4.8 & 5.6 \\
\hline Malaysia & 7.4 & 5.7 & 5.8 & 10.2 \\
\hline Pakistan & 6.1 & 5.2 & 4.2 & 4.7 \\
\hline Philippines & 5.7 & 3.1 & 4.1 & 8.3 \\
\hline South Korea & 10.0 & 6.4 & 4.9 & 4.7 \\
\hline Taiwan & 10.0 & 5.5 & 5.1 & 6.1 \\
\hline Thailand & 7.3 & 5.6 & 4.6 & 7.7 \\
\hline Vietnam & - & 6.8 & 7.6 & 6.4 \\
\hline Average & 7.1 & 5.9 & 5.8 & 6.5 \\
\hline
\end{tabular}

* Sources: The GDP growth data (1980-2010) is calculated from the World Bank, World Development Indicators. The earlier growth data (1965-80) is taken from Carlos Aquino Rodriguez, "Differences in the Economic Development of Latin America and East Asian Countries," paper presented at a conference of the Latin America-Caribbean and 
Asia-Pacific Economic and Business Association (LAEBA), Tokyo (Sept. 29-30, 2003). The growth data for Vietnam is from 1985-2010. The income inequality data is also from the World Development indicators; the years vary from 2005 to 2009. The growth data for Taiwan is up to 2009 and is from the Asian Development Bank, as is the inequality data. In this and the following tables I have provided simple and not weighted averages; GDP weighted averages would be swamped by China and India, and in most cases, would support my argument even more strongly.

Figure 1: GDP Growth, Asia and Latin America, 1980-2010

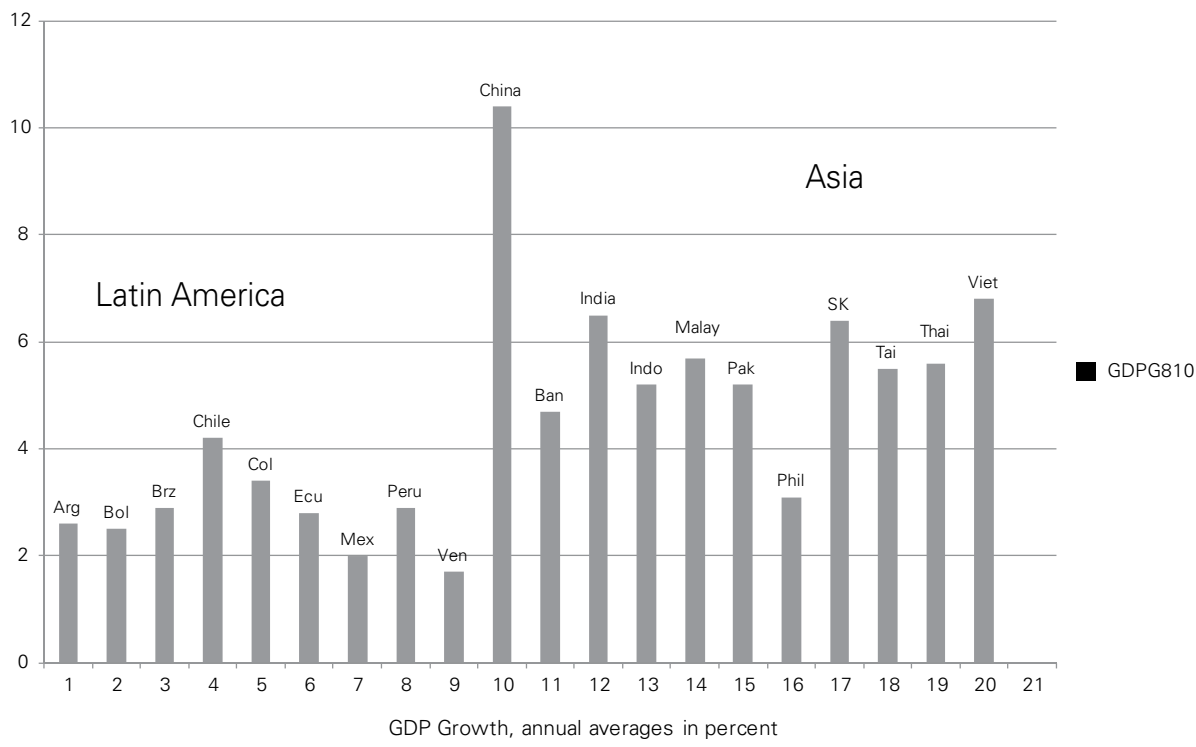

Figure 2: Income Inequality, Asia and Latin America, 2010

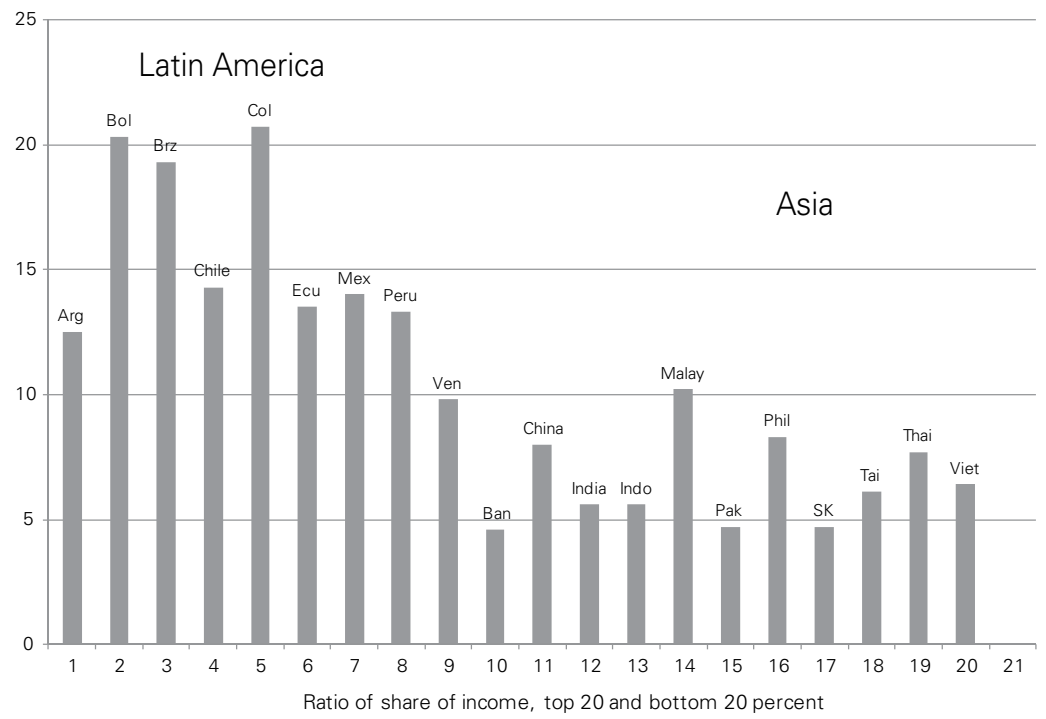

II202010 
Several trends observable in the data in Table 1 are noteworthy. First, even before Latin America's "lost decade" (the 1980s), major Asian economies grew faster than Latin American ones. The average annual growth rate in Asia between 1965 and 1980 was 7.1 percent to Latin America's 5.0 percent. If one takes out the two extreme cases - the slow growing India in Asia and the fast growing Brazil in Latin America - the average regional growth rates during 1965-80 were 7.6 and 4.5 respectively. Second, the gap in growth rates has widened since 1980. The average annual growth rate of a major Asian economy during 1980-2010 was 5.9 percent to 2.8 percent of a Latin American one. Even if one discounts the bad decade of the 1980s for Latin America, the differential in annual average growth rates remains significant: 5.8 percent in Asia and 3.6 percent in Latin America. Since 1980, some of the world's fastest growing economies - China, South Korea, India, Vietnam, and Malaysia - are all to be found in Asia. And finally, the growth performance of Asian economies is especially commendable considering that the levels of inequalities in these countries have remained relatively modest. Whereas the rich in an average Asian country are some six times richer than the poor, the rich in Latin America make nearly 15 times more than their poor (inequality in Latin America has come down fairly sharply over the last five years; the ratio of bottom 20 percent to top 20 percent in 2005 was closer to $1: 20$ ).

The puzzle of contrasting regional patterns of development has received a fair amount of analytical attention. For example, a popular argument during the 1980s attributed the superior capacity of Asian countries to generate economic growth and to escape the debt crisis that enveloped Latin America in that decade to its export prowess (e.g., Sachs, 1985). The argument was that countries like South Korea and Taiwan adopted market-friendly policies, including equilibrium exchange rates, which led them to promote exports instead of prioritizing import substitution of the Latin American variety. The prescriptive message was that open economies with market-friendly policies were better positioned to succeed at "development." This message both fed and reflected the emerging "Washington consensus" on development, which then went further in suggesting that debt ridden countries of Latin America should open their economies, privatize their public sectors, and more generally, shrink the state's role in the economy (Williamson, 1990; World Bank, 1991). Sophisticated alternate accounts of why East Asia's development performance was superior, or why the crises plaguing Latin America in the post-1974 period might have roots other than their interventionist states, existed already in the mid-1980s (e.g., Evans, 1986; Fishlow, 1987; and Johnson, 1986), but were drowned in the mind numbing "market fundamentalism" that prevailed in Washington of then. A barrage of scholarly criticisms sought to undermine this fundamentalist consensus, often emphasizing instead the positive role of state intervention in growth promotion (Amsden, 1989; Wade, 1990; Evans, 1995; Stallings, 1995; Chang, 2003; Rodrik, 2003; Kohli, 2004). With democratization, a new generation of left-leaning leaders in Latin America also started repudiating the "Washington consensus." And finally, as the economic performance of countries embracing the "Washington consensus" - many in 
Latin America-continued to falter, even the World Bank was led to suggest (2005) that their one-size-fits-all, market-friendly prescriptions might have been misleading, opening the way for alternate analyses (e.g. Serra and Stiglitz, 2008; Rodrik, 2011).

The roots of why many economies in Asia are growing faster with more modest inequalities than in Latin America run deep. Before addressing these "deeper" causal issues of national state and class construction in the past, and the subsequent role of the state in promoting alternate pathways, a discussion of some of the more proximate determinants of recent trends is necessary. The contrasting links that these regions have forged with the global economy are especially notable (see Tables 2, 3, 4 and 5). On the whole - and here I am fully aware that I am on a hazardous terrain, generalizing about regions that are quite diverse internally - Asian countries have created economies with high domestic savings rates, careful channeling of foreign investment into priority areas, significant capacity to export manufactured goods, and limited foreign debt. These economic trends emerged from planned activities of effective national states and helped stimulate economic growth. By contrast, many countries in Latin America that embraced the "Washington consensus" remain more dependent on the global economy, with lower domestic savings rates, smaller roles for national capital, higher dependence on foreign capital to supplement limited mobilization of domestic resources, exports focused on lower value added commodities, and relatively high levels of foreign debt. These trends too resulted from policy choices of different types of states at the helm in Latin America, less effective, with sharp elite-mass gaps and more globally complicit. Each of these issues requires further elaboration, especially how these characteristics might have contributed to differing economic performance.

Some basic data on national rates of savings in the two regions are provided in Table 2. Most growth economists view domestic savings as a key determinant of capital formation and economic growth (Rodrik, 2003, Ch. 1). The data in Table 2 and the illustrative scatter plot in Figure 3 (based on savings data for 2000, a point somewhere in the middle of the growth period considered, 1980-2010) thus provide some insights into the underlying, proximate determinants of cross-regional variation. The first and a relatively well known point to reiterate is that, over the last three decades, the average annual savings of Asian countries have been higher than in Latin America (Table 2). Notice that this was not always so; savings rates in Asia have risen steadily but not in Latin America. The relationship evident in Figure 3 suggests that it is reasonable to propose that countries with higher rates of savings in this sample have contributed to higher rates of economic growth, especially in the more recent period. Beyond the overall picture, what is noteworthy are the differential savings rates across the important economies of the region: whereas the savings rates of Brazil and Mexico have hovered around 20 percent for several decades, such Asian countries as China, Indonesia, South Korea, and 
more recently, even India, have constantly improved their savings rates, now close to or, as in the case of China, well above 30 percent (Table 2), contributing to their superior growth rates.

Table 2: Gross Domestic Savings (as a \% of GDP)*

\begin{tabular}{|c|c|c|c|c|c|c|}
\hline Latin America & 1960 & 1970 & 1980 & 1990 & 2000 & 2010 \\
\hline Argentina & 23 & 25 & 24 & 20 & 16 & 25 \\
\hline Bolivia & - & 17 & 19 & 11 & 9 & 24 \\
\hline Brazil & 20 & 20 & 21 & 21 & 16 & 18 \\
\hline Chile & 15 & 20 & 17 & 29 & 24 & 28 \\
\hline Colombia & 21 & 19 & 20 & 24 & 16 & 22 \\
\hline Ecuador & 10 & 9 & 20 & 22 & 26 & 21 \\
\hline Mexico & 15 & 21 & 25 & 22 & 22 & 24 \\
\hline Peru & 42 & 17 & 32 & 18 & 18 & 27 \\
\hline Venezuela, RB & 33 & 37 & 33 & 29 & 36 & 32 \\
\hline Average & 22 & 20 & 23 & 22 & 20 & 24 \\
\hline Asia & 1960 & 1970 & 1980 & 1990 & 2000 & 2010 \\
\hline Bangladesh & 8 & 7 & 2 & 10 & 18 & 18 \\
\hline China & - & 29 & 35 & 40 & 38 & 52 \\
\hline India & 12 & 15 & 15 & 23 & 24 & 32 \\
\hline Indonesia & 12 & 14 & 38 & 32 & 33 & 34 \\
\hline Malaysia & 26 & 24 & 30 & 34 & 47 & 39 \\
\hline Pakistan & - & 9 & 7 & 11 & 16 & 10 \\
\hline Philippines & 16 & 22 & 24 & 18 & 23 & 19 \\
\hline South Korea & 2 & 15 & 24 & 36 & 34 & 32 \\
\hline Taiwan & - & - & - & 27 & 24 & 31 \\
\hline Thailand & 14 & 21 & 23 & 34 & 31 & 33 \\
\hline Vietnam & - & - & - & 3 & 27 & 29 \\
\hline Average & 13 & 17 & 22 & 25 & 29 & 30 \\
\hline
\end{tabular}

*Source: World Bank, World Development Indicators, 2011. The data for Taiwan is from Asian Development Bank. A blank space indicates that the data was not readily available.

*Based on data in Tables 1 and 2. I took out the case of Venezuela in this scatter plot because, with its enormous (and misspent) oil based revenues, it is a real outlier in Latin America. 
Figure 3: Domestic Savings and GDP Growth

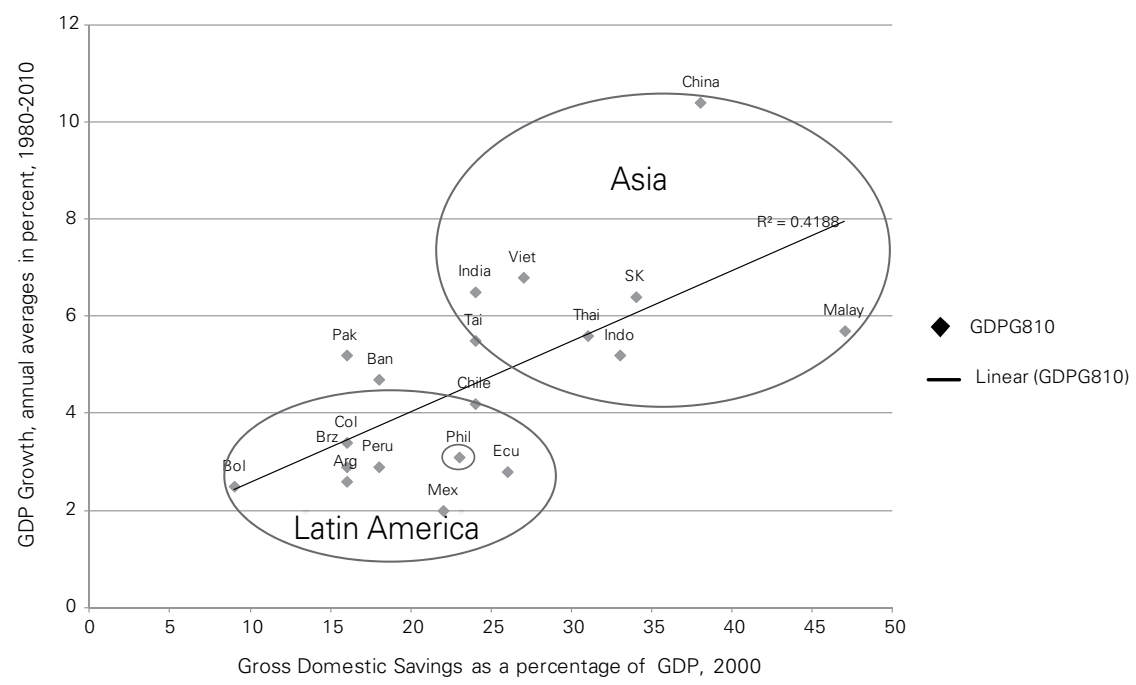

Why Asians save more than Latin Americans in s a complex issue, at least in part because the relationship between savings and growth can be mutual. What is important, however, is not to attribute such differences to some cultural givens. On the contrary, as already noted, the average rates of savings in Asian countries have improved steadily over time but not in Latin America; changes cannot be produced by constant givens. Among the forces propelling these divergent savings rates has been conscious government intervention in many Asian countries. Whereas the ruling elite in Latin America have often felt comfortable with their reliance on foreign capital, the more nationalist rulers of countries as diverse as South Korea and India have sought to minimize such dependence by promoting the accumulation of domestic resources. ${ }^{2}$ While strategies have varied, they have included mobilizing household savings, strengthening private equity markets and promoting savings and investment via the public sector.

Relatively stagnant rates of domestic savings and related high foreign debt have made Latin American economies more vulnerable to external economic pressures. Recent data on foreign debt of Asian and Latin American countries is reported in Table 3. While there are very few surprises in this data, a few points are worth discussing. First, notice the very high level of foreign debt vulnerability of Latin America in comparison to that of Asian countries around 1980 (or for that matter, around 1990); whereas Asian countries on the average owed only some 16 percent of their export earnings to foreigners, Latin Americans owed nearly 40 percent. In case it be thought that these figures mainly reflect the "export prowess" of Asia (Sachs, 1985), notice in Table 5 that Asians were not exporting all that much more in 1980 than

\footnotetext{
${ }^{2}$ It is difficult to provide specific country level detail in a short paper. I have analyzed these and related issues for at least the cases of South Korea, Brazil, and India in Kohli (2004).
} 
Latin Americans. ${ }^{3}$ Additional factors contributed to Latin America's relative debt burden. Latin Americans simply borrowed more heavily in the aftermath of oilprice hike in 1974, when import bills increased and real interest rates declined; this is evident in the higher debt to GNI ratios in Latin America in 1980 (Table 3). Moreover, Fishlow (1987) argued convincingly that external shocks hit Latin America more seriously than Asia.

The scatter plot in Figure 4 suggests that the level of debt in 1980 is a good predictor of growth performance during the subsequent three decades. A full story of how these high levels of debt contributed to the "debt crisis" and the related "lost decade" of development in Latin America during the 1980s need not be told in this short paper (see e.g., Solimano, 2006). Here I can only offer some suggestive causal links.

Table 3: Foreign Debt Indicators*

\begin{tabular}{|c|c|c|c|c|c|c|}
\hline & \multicolumn{3}{|c|}{ Debt Service as \% of Export } & \multicolumn{3}{|c|}{ Debt as $\%$ of GNI } \\
\hline Latin America & 1980 & 1990 & 2010 & 1980 & 1990 & 2010 \\
\hline Argentina & 42 & 37 & 16.7 & 36 & 46 & 36 \\
\hline Bolivia & 36 & 38.6 & 9.3 & 60 & 92 & 28 \\
\hline Brazil & 68 & 22.2 & 19.0 & 31 & 27 & 17 \\
\hline Chile & 45 & 25.9 & 15.2 & 46 & 65 & 46 \\
\hline Colombia & 18 & 40.9 & 21.0 & 21 & 45 & 23 \\
\hline Ecuador & 35 & 32.5 & 9.4 & 52 & 132 & 23 \\
\hline Mexico & 51 & 20.7 & 9.8 & 31 & 41 & 20 \\
\hline Peru & 46 & 10.8 & 16.7 & 48 & 79 & 31 \\
\hline Venezuela & 30 & 23.3 & 8.8 & 44 & 72 & 14 \\
\hline Average & 41.2 & 28.0 & 14 & 41 & 66 & 26 \\
\hline Asia & 1980 & 1990 & 2010 & 1980 & 1990 & 2010 \\
\hline Bangladesh & 26 & 25.8 & 4.7 & 22 & 40 & 23 \\
\hline China & 4 & 11.7 & 3.3 & - & 16 & 9 \\
\hline India & 10 & 31.9 & 5.6 & 11 & 27 & 17 \\
\hline Indonesia & 14 & 33.0 & 16.6 & 28 & 64 & 26 \\
\hline Malaysia & 7 & 12.6 & 5.2 & 27 & 36 & 35 \\
\hline Pakistan & 18 & 21.3 & 15.2 & 39 & 50 & 31 \\
\hline Philippines & 29 & 27.0 & 18.4 & 54 & 69 & 36 \\
\hline South Korea & 20 & 11.3 & - & 55 & 13 & 32 \\
\hline Taiwan & - & 0.5 & 2.6 & 14 & 11 & 26 \\
\hline Thailand & 20 & 16.9 & 4.8 & 26 & 33 & 31 \\
\hline Vietnam & - & - & 1.7 & - & - & 36 \\
\hline Average & 16.4 & 19.2 & 7.7 & 31 & 36 & 27 \\
\hline
\end{tabular}

*Source: Most data for debt service as a percentage of exports and for debt as percentage of Gross National Income (GNI) is from online development indicators of the World Bank. Data for Taiwan (for 2010) is for 2009 and is from the Asian Development Bank. The data for South Korea (for 2010) is from the OECD. The South Korean and Taiwanese data for 1980 is actually from 1983 and is taken from Fishlow (1987) Table 1.

*Based on data in Tables 1 and 3.

${ }^{3}$ The case Sachs (1985) made for the vastly superior export performance of Asian countries in the early 1980s rested on choosing the four most successful Asian exporters, Indonesia, Korea, Malaysia and Thailand. 


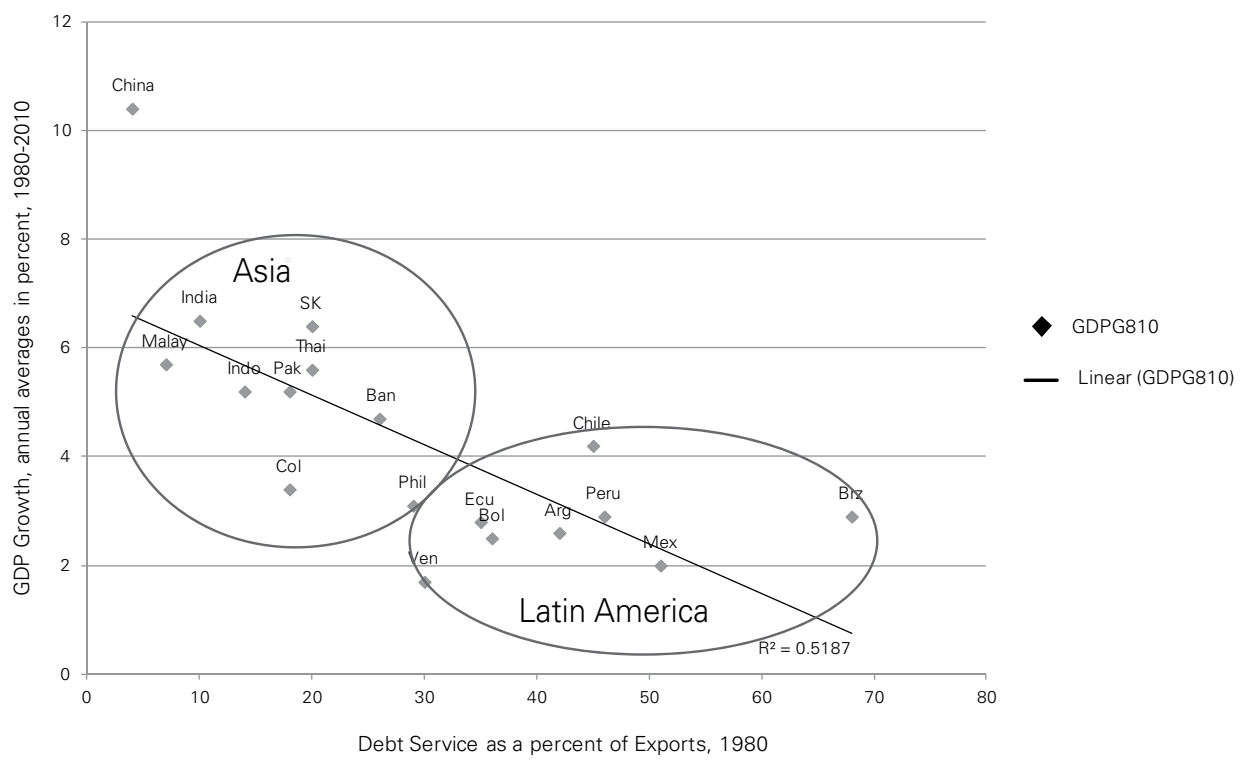

Following the Mexican financial crisis of 1982, the highly indebted Latin American countries found themselves desperate for external finance. This often led them to enter arrangements with the IMF in exchange for a package of policies popularly known as "structural adjustment" policies. There is some doubt whether these policies were truly designed to promote growth; it may well be that their primary purpose instead was to ensure that foreign debt was paid off (Stiglitz, 2003). Be that as it may, it is difficult to claim today — as it was during the 1980s - that what held Latin America back was poor management of exchange rates. ${ }^{4}$ Two decades of structural adjustment policies further integrated Latin American economies with the global economy, without delivering on the promise of renewed rapid growth (Stallings and Peres, 2000); when growth picked up and debt levels declined during the last decade, much of this was related to commodity exports and to the post-Washington consensus policies of newly elected democratic regimes Meanwhile, most Asian countries escaped the debt crisis, using state intervention to propel their economies and to integrate with the world economy on their own terms. The causal role of debt in the growth story then probably runs through the vulnerability of some states that the debt caused, and led them, in turn, to adopt policies that were probably not even meant to be growth enhancing.

What is also worth repeating is a point already made above, namely, that the

\footnotetext{
${ }^{4}$ It is possible that a different type of exchange rate problem has emerged by now, one that is caused by excessive dependence on commodity exports, leading to the so called "Dutch disease," even in countries that are not 'cursed' by oil. For a discussion, see Bresser-Pereira (2011).
} 
roots of the "debt crisis" in Latin America were not simply the penchant of Latin America for import substitution. While there is no denying the export success of many such Asian countries as South Korea and Taiwan, the underlying issues were more complex than import substitution versus export promotion. During the 1970s, for example, both South Korea and Brazil combined import substitution and export promotion, with South Korea out performing Brazil on the export front by a considerable margin. The complex underlying determinants included an efficacious South Korean state that was deeply interventionist and deeply committed to export promotion (Kohli, 2004).

As Latin Americans restructured their economies to pay off external debt, along with some debt forgiveness, the debt service ratio declined. What is notable in Table 3 is that this decline was relatively sharp during the 1980s, when economic growth vanished, and much more modest between 1990 and 2000, when growth resumed. This further suggests that economic growth might have been sacrificed so the external debt could be paid off. Also worth noting in the debt data are the recent levels of debt in Asia and Latin America. The levels of debt in Latin America have declined pretty sharply in recent years, especially between 2005 and 2010. This in part reflects that Latin Americans have by now paid off their debts, though at significant costs to national income, and in part a function of renewed growth, including exports, though mainly in commodities (more on this below).

Latin America has always depended heavily on foreign investment for its economic growth, with fairly mixed results. Data on the stock of foreign capital in Asia and Latin America at two points in time - nearly four decades apart - is presented in Table 4. While this data is not without problems, it documents in a general way the greater role of foreign capital in Latin America than in Asia, nearly by a factor of two. It is not surprising that the term "dependent development" was coined to capture the dynamics of these political economies (Cardoso, 1973; Evans, 1979). Recent data on inflows of foreign capital (also Table 4) further confirm this distinction. Even during the 1980s, for example, when direct foreign investment inflows decelerated in Latin America, they were still greater than in Asia. This trend has continued into the most recent period. Since the rates of savings and investments vary in the two regions, FDI as a proportion of capital formation also tells a similar story. During the 1980s foreign direct investment flows contributed less than 5 percent of capital formation in Asian countries and their role inched up to some 10 percent over the last two decades. By contrast, after starting from a similar average level, foreign direct investment over the last decade has come to constitute nearly 20 percent of capital formation in Latin America. ${ }^{5}$ That is to say, nearly a fifth of economic growth in Latin America today is propelled by direct foreign investments (and this does not include portfolio investments, whose role in real growth is difficult to sort out).

\footnotetext{
${ }^{5}$ These figures are calculated from the online data on "foreign direct investment," United Nations Conference on Trade Development.
} 
Table 4: Indicators of Foreign Direct Investment*

\begin{tabular}{|c|c|c|c|c|}
\hline & \multicolumn{2}{|c|}{ Stock of FDI } & \multicolumn{2}{|c|}{ FDI Inflows as $\%$ of GDP } \\
\hline & $\begin{array}{l}\text { "Penetration } \\
\text { Measure," } 1967\end{array}$ & $\begin{array}{l}\text { AS \% of } \\
\text { GDP, } 2010\end{array}$ & $1980-89$ & $1990-2010$ \\
\hline \multicolumn{5}{|c|}{ Latin America } \\
\hline Argentina & 6137 & 23.4 & 0.6 & 2.2 \\
\hline Bolivia & 6047 & 35.8 & 0.8 & 4.4 \\
\hline Brazil & 6712 & 22.9 & 0.7 & 2.2 \\
\hline Chile & 10100 & 67.7 & 2.1 & 5.7 \\
\hline Colombia & 5211 & 29.3 & 1.4 & 2.9 \\
\hline Ecuador & 2598 & 18.1 & 0.8 & 2.7 \\
\hline Mexico & 4348 & 31.9 & 1.1 & 2.5 \\
\hline Peru & 7880 & 26.9 & 0.1 & 2.8 \\
\hline Venezuela & 10300 & 9.9 & 0.1 & 1.8 \\
\hline Average & 65935.0 & 29.5 & 0.8 & 3.0 \\
\hline \multicolumn{5}{|l|}{ Asia } \\
\hline Bangladesh & - & 6.1 & 0 & 0.4 \\
\hline China & - & 9.9 & 0.2 & 3.6 \\
\hline India & 664 & 12.1 & 0 & 1.1 \\
\hline Indonesia & 732 & 17.2 & 0.3 & 0.9 \\
\hline Malaysia & 10,000 & 42.9 & 3.1 & 4.3 \\
\hline Pakistan & 2158 & 12.2 & 0.1 & 1.3 \\
\hline Philippines & 3885 & 13.2 & 0.4 & 1.5 \\
\hline South Korea & 592 & 12.6 & 0.1 & 0.6 \\
\hline Taiwan & - & 14.2 & - & 0.8 \\
\hline Thailand & 1372 & 39.9 & 1.1 & 2.9 \\
\hline Vietnam & - & 9.8 & 0 & 6.4 \\
\hline Average & 2772 & 17.3 & 0.5 & 2.2 \\
\hline
\end{tabular}

*Source: The "Penetration Measure" (or PEN) is taken from Volker Bornschier and Christopher Chase-Dunn, Transnational Corporations and Underdevelopment, Praeger, New York, 1985, pp. 156-9. The authors used capital stock data for 1967 calculated by OECD and weighted it by total stock of capital and labor force (for details see p. 91); the higher the number, the greater the stock of foreign capital in a national economy. The stock data for 2010 is from the online data on "foreign direct investment," United Nations Conference on Trade and Development. The flow data is calculated from the World Banks' World Development Indicators.

*Based on data in Tables 1 and 4

*Based on data in Tables 1 and 4. 
Figure 5: Foreign Direct Investment (stock) and GDP Growth

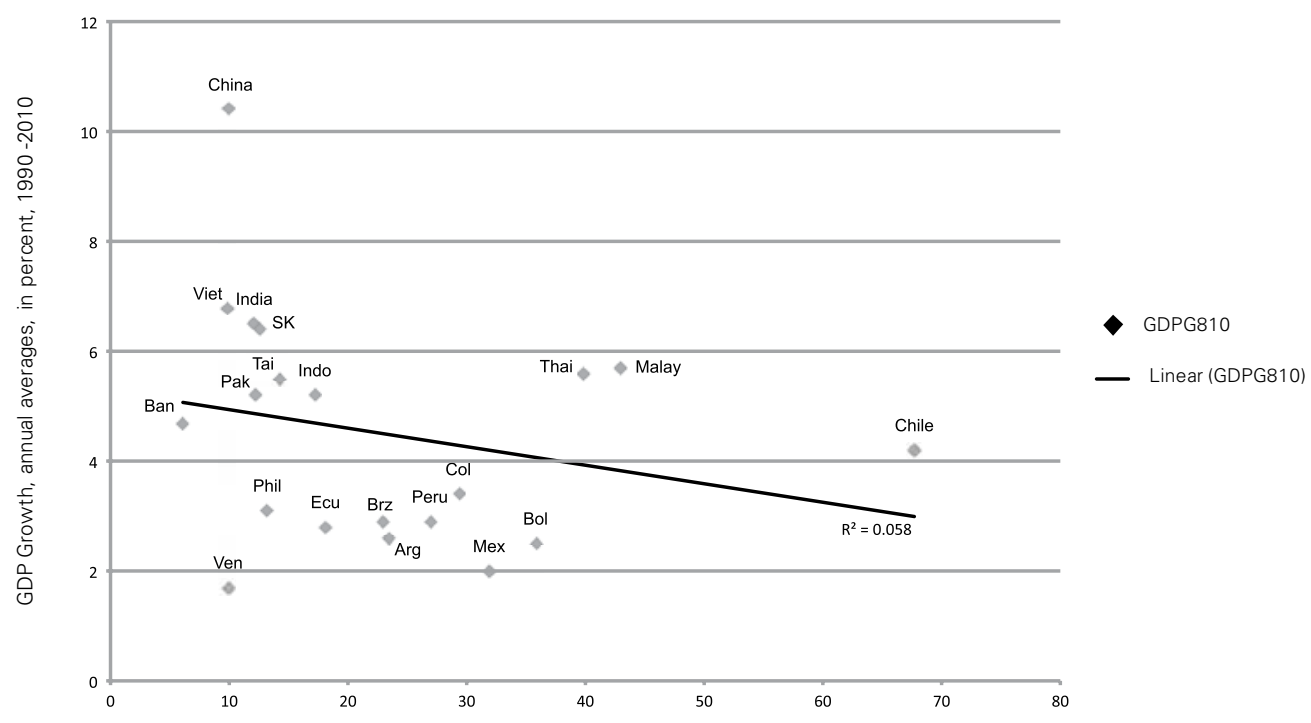

Figure 5A: Foreign Direct Investment (flows) and GDP Growth

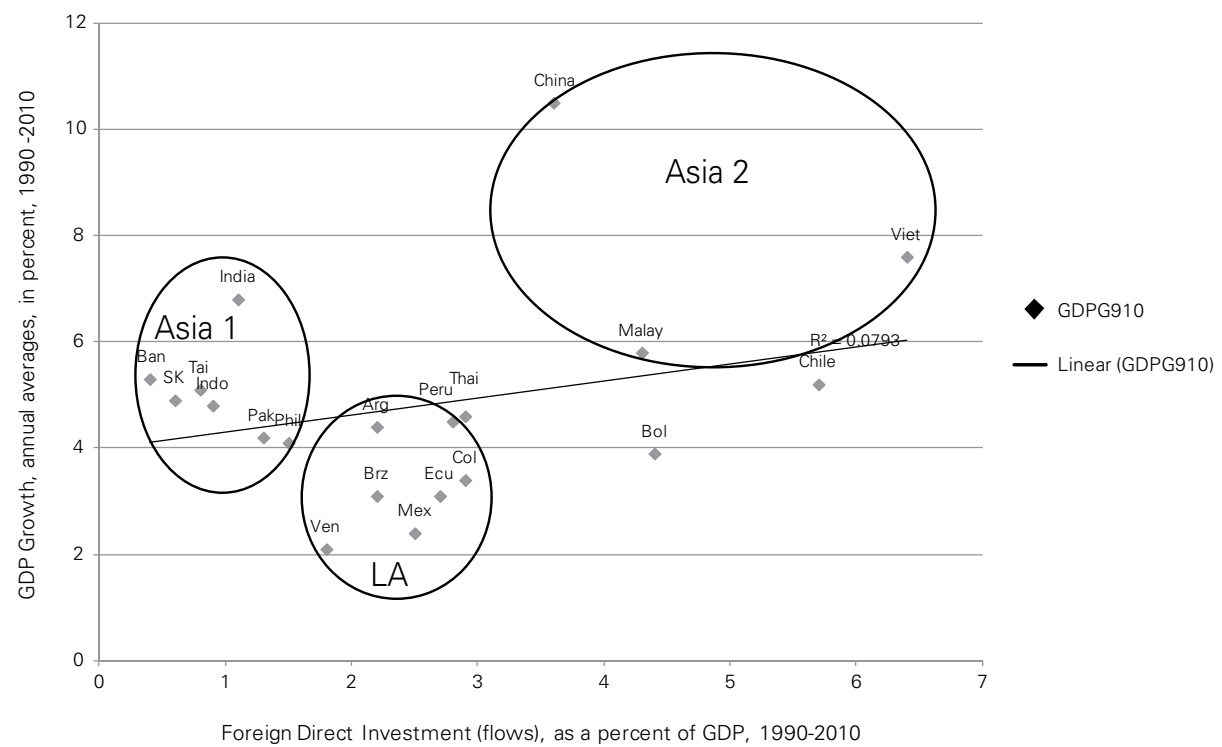

How should one assess the role of FDI in the growth processes of the two regions? The related scholarly terrain is controversial, well rehearsed, and largely inconclusive. For example, earlier dependency research suggested nearly an inverse relationship between FDI (especially higher stocks) and economic growth, pointing 
to such causal factors as the role of FDI in absorbing national savings, discouraging national entrepreneurs, and enhancing pressure on balance of payments (Bornschier and Chase-Dunn, 1985). This research was subsequently criticized (e.g., Firebaugh, 1992). Though the statistical debate remained inconclusive, the policy debate was overtaken, both by the 'Washington consensus,' that favored such investments, and by the growing need of debt ridden countries for such investments as a source of foreign exchange. Juxtaposing recent Asian and Latin American data also does not provide any clear cut conclusions.

As is evident in Figures 5 and $5 \mathrm{~A}$, the relationship between stock or flows of FDI and recent economic growth is fairly weak. Even within Asia, countries such as India and South Korea have grown handsomely with low levels of FDI while others, such as Malaysia, China and Vietnam, have achieved high rates of economic growth with the help of FDI. What one can say from this data instead then is that there is little support here for the neo-liberal argument that greater integration into the world economy along the axis of capital is good for economic growth. However, there is also little support for the more radical argument that such integration is actually bad for growth.

The question of whether foreign investment helps or hurts economic growth is probably the wrong question. Much depends on the terms on which FDI comes into a developing country. FDI is more useful when it promotes manufactured exports and provides access to new technology and management. This, in turn, directs attention to the "bargaining capacity" of national states vis-à-vis multinational corporations. In this context, notice once again some of the regional patterns evident in Figure 5A. Most countries in Latin America (with the significant exception of Chile) have since 1990 received moderately high amount of FDI (some $2 \%$ to $3 \%$ of GDP) and grown at fairly sluggish rates; they are concentrated towards the bottom-middle in Figure 5A. These countries have needed to depend on external resources, in part to compensate for low rates of domestic savings, and in part as a source of foreign exchange necessary to pay off a large foreign debt. The greater such dependence, the more difficult it has been for Latin American states to set the terms on which foreign investors invest. As a result, FDI in these countries has been concentrated either in commodity exports (e.g., mining) or in manufacturing and services for domestic consumption (e.g., automobiles, electricity, telecommunication; Velde, 2003, Ch. 5).

By contrast, there are two modal patterns evident in Asia, both of which are worth a comment. The countries in the "Asia 1" group (Figure 5A) constitute the main pattern in Asia; typified by India and South Korea, these are countries with relatively low rates of FDI inflows and moderately high rates of economic growth, financed mostly by high rates of national savings. With limited dependence on foreign investment, autonomous national states in these countries have often channeled FDI into the promotion of manufactured exports or other "high priority" areas. The same focus on manufactured exports is also evident in the few countries in the "Asia 2" group, but with an important distinction: these countries depend very heavily on FDI. How does one explain the capacity of national states under 
such conditions of "dependency" to channel FDI into priority areas? The answer in part has to do with the cheap and disciplined work force in countries like China and Vietnam that makes them attractive to foreign investors. However, what also enhances the bargaining capacity of these states - or, at least reduces their dependence on Western countries - are the diverse and regional origins of their FDI. For example, anywhere from half to two thirds of foreign investment going into China originates in Hong Kong and Taiwan. ${ }^{6}$ In Vietnam also, $66 \%$ of total FDI inflows between 1990 and 2006 originated in Taiwan, Singapore, Korea, Japan, and Hong Kong (Nguyen and Nguyen, 2007, Table 20). Contrast this with the typical pattern in Latin America, where, on the average, some 44\% of FDI in 1995 originated in the USA and nearly $30 \%$ in Europe (Velde, 2003, Table 37). Given the overall pattern of FDI in Asia and Latin America then, it becomes clear why Latin American countries are more likely than Asian countries to pursue economic policy advice originating in Washington-based international development institutions.

Finally, some data on patterns of exports from Asia and Latin America are provided in Table 5. While Asians clearly export more than Latin Americans, the differences in the recent past were not dramatic. As noted above, this was already so in 1980. Since the embrace of neo-liberal policies, the overall exports of Latin American countries grew over the 1980s, with a lion's share of these earnings going towards paying their accumulated foreign debt. The gap between Asian and Latin exports has widened over the last two decades. However, if one excludes the more extreme case of Malaysia, Asians in 2010 exported 40 percent of their GDP to some 30 percent for an average Latin American country. This difference is significant but not dramatic. Based on this, it would be hard to continue to attribute superior growth performance of Asian countries to their relative export prowess; note the weak relationship in Figure 6. The real dramatic difference in export patterns across Asia and Latin America lies instead in the composition of their exports: whereas Asian countries mainly export manufactured goods, Latin Americans mainly export commodities (Table 5). Only Brazil and Mexico in Latin America (notice, not Chile) are significant exporters of manufactured goods. The remaining Latin countries continue to fit the profile of what Cardoso and Faletto (1979) long back characterized as "enclave economies", with heavy foreign investment and commodity exports. By contrast, the preponderance of manufactured goods among Asia's exports is really noteworthy. It underlines the relative competitiveness of Asian economies and thus points to one more component of their superior economic growth (Figure 7). ${ }^{7}$ The preponderance of manufactured exports also points

\footnotetext{
${ }^{6}$ See Branstetter and Lardy, 2008, Figure 16.4, p. 643 and footnote 11, p. 642. The foreign investment originating in Hong Kong, Taiwan and "other" locations (much of which is from Taiwan but routed via such tax havens as Cayman Islands) clearly constitutes a majority of foreign investment coming into China.

${ }^{7}$ It may be objected that, with lower per capita incomes and lower labor costs, it is easier for Asian countries to compete globally than for the middle income Latin American countries. While there is some truth to this proposition, two qualifications are important. First, the relationship between
} 
to one factor that might contribute to a more egalitarian income distribution in Asia (Figure 8): a focus on labor intensive manufacturing may help create more and better-paid jobs in manufacturing.

Table 5: Exports*

\begin{tabular}{|c|c|c|c|c|c|}
\hline \multirow[b]{2}{*}{ Latin America } & \multicolumn{3}{|c|}{ Exports (\% GDP) } & \multicolumn{2}{|c|}{$\begin{array}{l}\text { Manufactured Exports } \\
\text { (\% Exports) }\end{array}$} \\
\hline & 1980 & 1990 & 2010 & 1990 & 2010 \\
\hline Argentina & 5 & 10 & 22 & 29 & 33 \\
\hline Bolivia & 25 & 23 & 41 & 5 & 6 \\
\hline Brazil & 9 & 8 & 11 & 52 & 37 \\
\hline Chile & 23 & 34 & 39 & 11 & 13 \\
\hline Colombia & 16 & 21 & 16 & 2 & 23 \\
\hline Ecuador & 25 & 33 & 33 & 2 & 10 \\
\hline Mexico & 11 & 19 & 30 & 43 & 76 \\
\hline Peru & 22 & 16 & 25 & 18 & 14 \\
\hline Venezuela & 29 & 39 & 29 & 10 & 4 \\
\hline Average & 18.3 & 22.5 & 27 & 21.6 & 24 \\
\hline Asia & 1980 & 1990 & 2010 & 1990 & 2010 \\
\hline Bangladesh & 5 & 6 & 18 & 77 & 88 \\
\hline China & 11 & 19 & 30 & 72 & 94 \\
\hline India & 6 & 7 & 22 & 70 & 64 \\
\hline Indonesia & 34 & 25 & 25 & 35 & 37 \\
\hline Malaysia & 57 & 75 & 97 & 54 & 67 \\
\hline Pakistan & 12 & 16 & 14 & 79 & 74 \\
\hline Philippines & 24 & 28 & 35 & 38 & 86 \\
\hline South Korea & 32 & 28 & 52 & 94 & 89 \\
\hline Taiwan & - & - & 64 & - & 99 \\
\hline Thailand & 24 & 34 & 71 & 63 & 75 \\
\hline Vietnam & - & 36 & 68 & - & 60 \\
\hline Average & 22.8 & 27.4 & 45 & 64.6 & 76 \\
\hline
\end{tabular}

* Source: Much of the data is from World Development Indicators. The data for Taiwan is calculated from Taiwan Statistical Data Book, 2011.

*Based on data in Tables 1 and 5.

*Based on data in Tables 1 and 5.

*Based on data in Tables 1 and 5 .

per capita incomes (say, in 1980) and growth rates (say, 1980-2010) in the countries considered here is only mildly supportive of this proposition (" $\mathrm{r}$ square" is 0.27 ). And second (and related to this "mild" relationship), it is the case that such middle income countries of Asia as South Korea, Taiwan and Malaysia continue to be successful exporters of manufactured goods. 
Figure 6: Exports and GDP Growth

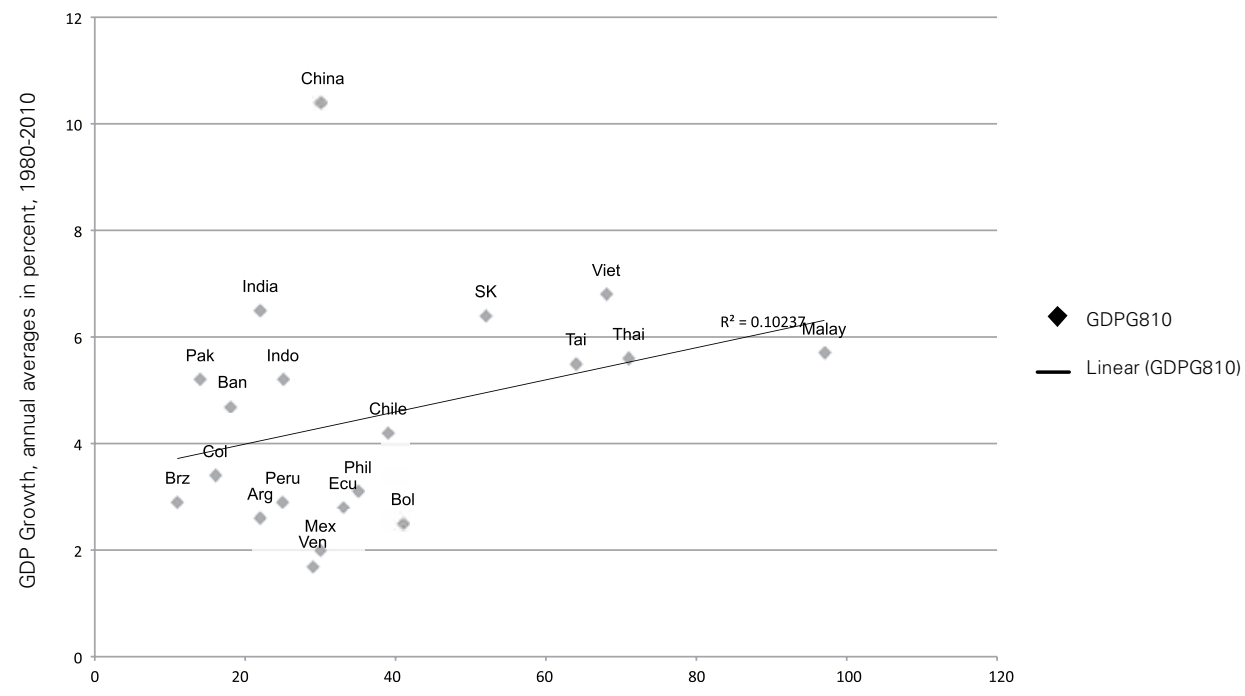

Exports as a percentage of GDP, 2010

Figure 7: Manufactured Exports and GDP Growth

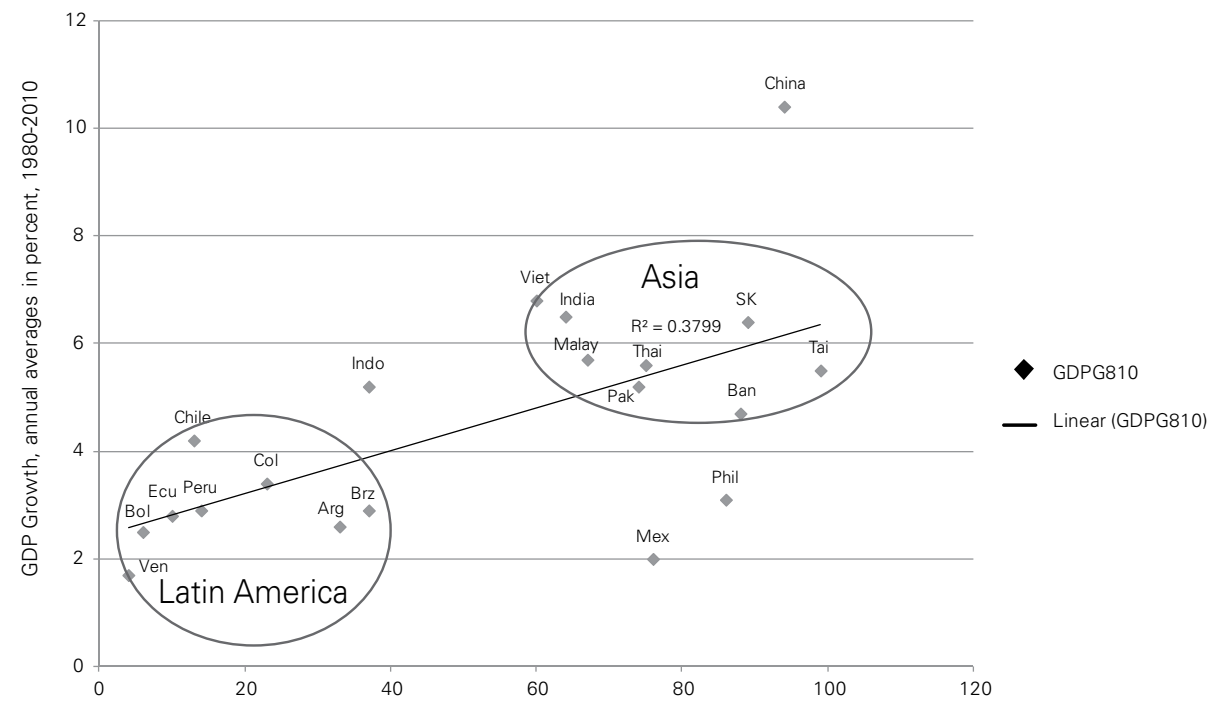

Manufactured exports as a percent of total exports, 2010 
Figure 8: Manufactured Exports and Income Inequality

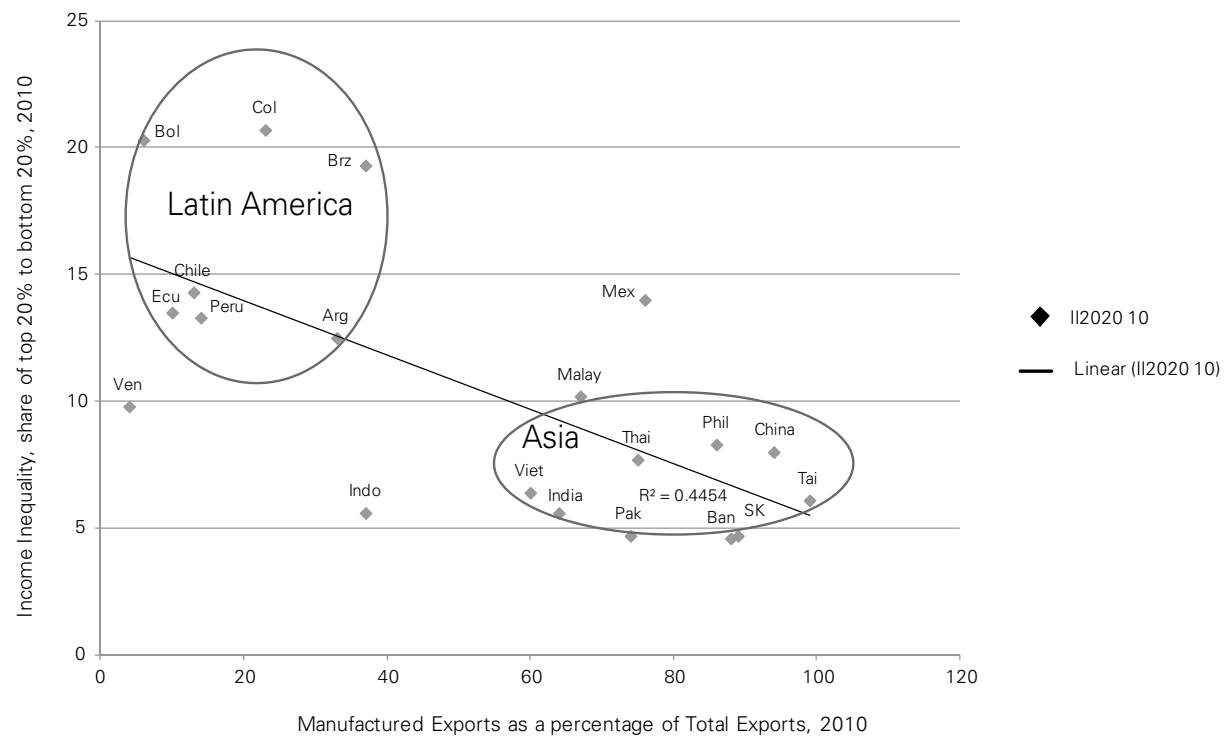

The "Washington Consensus" on development was supposed to help Latin American countries grow faster by employing their factors of production more efficiently, including labor, which, in turn, ought to have helped a better income distribution. Unfortunately, much of this did not come to pass (Stallings and Peres, 2000), at least until recently when many countries abandoned the straight jacket of neoliberal policies. Instead, Asian countries, that did not readily embrace policies dictated from Washington, have continued to grow faster with more modest inequalities over the last three decades. The underlying determinants of such divergent patterns of development are complex. What the simple exercise above documents is that Asia and Latin America continue to pursue different models of development; Asia's development model is more nationalist and that of Latin America more dependent. The Asian model has been characterized by high rates of domestic savings, limited foreign debt, limited dependence on foreign investment, and a significant capacity to export manufactured goods. By contrast, Latin American economies continue to save less, depend more on foreign capital for their growth, and export more commodities than manufactured goods. While simple scatter plots only highlight some associations, the data above does seem to cumulatively suggest that these alternate models of development have been consequential, especially for molding growth patterns.

\section{ASIA VERSUS LATIN AMERICA, POLITICAL ORIGINS OF ALTERNATE PATHWAYS}

If Asians and Latin Americans have pursued different models of development, especially over the last three decades, what are the deeper determinants of these 
alternate pathways? How, and in what sequence, has the causal story of Asia unfolded differently than that of Latin America? Any full story would have to be rather complex, taking into account differing geographies, resource endowments, and even colonial histories (see, e.g. Krieckhaus, 2006). Less ambitiously, my main proposition is that the origins of the differing pathways traversed by Asia and Latin America are political, rooted in differing patterns of state intervention, which in turn reflect the different processes of state formation in the two regions around the period of WWII. Generalizing hugely, and again somewhat dangerously, decolonization in Asia created significant political discontinuities, which in turn led to modified class relations, altered external relations, and more nationalist development choices. By contrast, there was no such discontinuity in Latin America in the post-WWII period; state and class formations modified of course, but only incrementally, continuing along the grooves of dependent development of a much earlier historical origin.

Following WWII, for example, China had a major communist revolution and the world's most significant non-communist nationalist movement captured state power in India. The Asian giants thus began their sovereign development experiments by focusing first and foremost on state consolidation. Once in power, the nationalistically inclined Chinese communists (Johnson, 1962) minimized Western economic and political influence on China, eliminated China's comprador classes, and created a well organized state that penetrated the Chinese society deeply (Schurmann, 1968). While India's democratic state was less efficacious than the Chinese communist state, India's nationalist leaders also prioritized sovereignty and state consolidation. They too minimized the role of old landed classes that collaborated with the British, as well as keeping at bay new political and economic dependencies (Nayar, 1989). The Asian giants then used the power of newly consolidated states to create nearly autarkic economies in the early decades (say, 1950 to 1980). While these experiments were hardly without costs, even serious costs in areas of state repression and state-led upheavals(China), slow and lingering poverty (India), and sluggish economic growth (both China and India), there is no denying that state consolidation laid the foundation for a nationalist model of development in both China and India, which is now paying off.

Decolonization created a variety of political outcomes in the rest of Asia, with one shared commonality, namely, the creation of sovereign, new, and, for the most part, effective states. For example, the Japanese lost WWII and, along with that, their power and investments in such colonies as Korea and Formosa; this led to a new political beginning in the partial countries of South Korea and Taiwan. The Dutch were forced out of Indonesia, as were the British from Malaysia. Both the French and the Americans were eventually defeated militarily in Vietnam. While there were exceptions (e.g., the Philippines), well organized mass nationalist and/ or revolutionary forces consolidated power in most Asian countries following WWII. It might be objected that countries like South Korea or Pakistan very quickly developed new dependencies, this time on the U.S. This is true but with one important qualification. These new dependencies were mainly a product of the 
Cold War and thus were security-oriented in nature. For the most part, countries like South Korea were left alone to pursue their economic development, even gaining preferential resources and treatment from the U.S. as a quid pro quo for security arrangements (Hart-Landsberg, 1993).

In contrast to Asia, decolonization in Latin America was in the distant past. State consolidation occurred mainly in the inter-War period. Unlike the Asian pattern of anti-colonial mass mobilization, the underlying processes leading to state consolidation in Latin America often involved struggles between rival elites, especially struggles between centralizing and regional elites. Following WWII newer political formations emerged in many Latin American countries too, but there was more continuity than discontinuity in the social base of state power, in patterns of economic dependency, and in developmental choices (Cardoso and Faletto, 1979). Most of these regimes readily embraced the emerging Western alliance, led by the United States. ${ }^{8}$ Consider, for example, the case of the most important Latin American country, Brazil. While a new democratic regime of sorts replaced an authoritarian regime following WWII, Skidmore (1967) skillfully demonstrated the elements of continuity in the pre-and the post-WWII political economy of Brazil. In Brazil, Vargas, the authoritarian leader of the pre-War period, even came back to power, this time as a democratically elected president.

The Cuban revolution marked a moment of potential change in Latin American politics, in the direction of activist states supported by mass politics. From Goulart to Allende, a variety of nationalists, populists, and social democrats emerged to give voice to new political forces of the region. The United States - the regional hegemon, committed to open economies, especially in its "backyard" - sought to co-opt the emerging political restlessness in a liberal direction via the Alliance for Progress. When such efforts did not succeed, the U.S. just as readily threw its weight behind more reactionary political forces that would provide favorable economic policies. This tilted the balance of power within Latin American societies, retarding the trend towards more nationalist and plebiscitary politics. Landed oligarchs, foreign investors, and militaries — often trained in the United States — felt threatened by the new direction. A variety of military coups that occurred in Latin American countries during the 1960s and the 1970s brought to power elites who were inclined to cooperate politically and economically with the U.S. on the one hand and to pursue a highly elitist and a dependent model of development at home on the other hand. Scholars coined the term "associated-dependent development" to capture these new types of Latin American political economies (Cardoso, 1973).

While anti-colonial mass movements consolidated power in many Asian countries during the 1950s and the 1960s, similar political forces were thwarted in Latin America. What emerged in the latter instead was a variety of narrower elitist ar-

\footnotetext{
${ }^{8}$ As evidence notice that, starting around 1955, Latin American countries started voting in the United Nations with the "West" and not with Afro-Asian (1970) "nonaligned" group. See Newcombe (1970).
} 
rangements under American tutelage. These contrasting political developments cast the die for a longer term divergence in political and economic evolution of the two regions. Among the developmental changes in the two regions that can be traced back to these earlier contrasts in state construction are: land reforms and related patterns of inequalities; strategies towards dependence on foreign capital; and the role of national capital and indigenous technology, including trained manpower, in industrialization strategies. These contrasting policy choices in turn often reinforced the character of developmental states of the two regions, more nationalist in Asia and more dependent in Latin America.

Take, for example, the issue of land reforms. We know that land reforms were a lot more successful in Asia than in Latin America (Evans, 1986). It is important to recall the strong political motivation in the pursuit of land reforms (Tai, 1974). Traditional land owning elites not only limited the reach of the state into the countryside but comprador classes often had their roots in landed wealth. The process of consolidating nationalist states in Asian countries was thus aided by the elimination of a variety of "feudal" types of intermediate elites. Land reforms enhanced the reach of the state on the one hand, and moderated inequalities of wealth and power in the countryside on the other hand. Such developments were clearest in the communist cases of China and Vietnam. The threat of communism, in turn, also facilitated significant land redistribution in such other cases as South Korea and Taiwan. Even in an India - where land reforms were mostly a failure - the largest zamindars (traditional large land holders who had often cooperated with the British colonial government in India) were broken down and pressures of democracy mitigated the "urban bias" of the polity, leading to reasonable terms of trade between the city and the countryside. A similar outcome unfolded in Indonesia, where the mechanism was less democratic politics but more threats of peasant rebellion. Of course there were exceptions, such as the Philippines and Pakistan. These cases continued to resemble Latin American cases, where landed oligarchs survived well into the modern period, state consolidation remained incomplete, and dependence on the U.S. was significant.

During the 1950s and the 1960s, the well known import substitution model of development (ISI) was pursued in both Asia and Latin America. What is important to reiterate here are the significant differences across Asian and Latin American ISI strategies. On the whole, Latin American countries pursued ISI with foreign investors producing consumer goods for Latin elites behind high tariff walls. By contrast - again, generalizing hugely - ISI policies in Asia focused on heavy industry that was promoted by domestic resources and for domestic markets. These contrasting policies both reflected the contrasting political preferences of more nationalist versus more dependent states on the one hand and further reinforced these tendencies, with future consequences, on the other hand.

In Communist China, for example, a heavy industrial base was laid down by public investments. This involved mobilization of domestic resources, often via brutal political mechanisms, and then borrowing and slowly but surely indigenizing technology. Public investments also played a crucial role in India's heavy industry 
oriented ISI, but then so did indigenous capital. The Indian state also limited the role of foreign capital in India's development and prioritized training indigenous technical manpower to aid its industrial ambitions. When the dust of civil war and reconstruction settled in South Korea (say, around 1960), the government there pursued simultaneously heavy industry oriented ISI and a state subsidized drive to promote light industry exports, both financed by domestic savings. Here too a direct role for foreign capital was minimized and spread of education helped rapid industrialization. Notice that none of these cases were cases of "easy ISI" that was pursued in Latin America, which I discuss below. Asian countries by contrast pursued "difficult ISI." Committed to creating modern but sovereign political economies, they initiated policies that helped mobilize domestic resources, limited foreign capital, and built indigenous technology and industry. Of course, a South Korea or a Taiwan grew much faster in this earlier period than an India or a China (for an analysis of why, see Kohli, 2004), but in all of these cases foundations of more nationalist political economies were built by conscious political decisions of post-colonial states.

The Latin American version of ISI, by contrast, has been rightly characterized as "easy ISI." The term is apt because Latin American leaders seldom took the difficult decisions that might — say, over the medium term — enhance national savings, build national technology, and lay the foundation for heavy industry. One is tempted to impute fairly distinct developmental motivations to Latin American rulers: whereas many rulers in Asia were committed to creating strong and modern national political economies, development for Latin American rulers often meant enhancing national incomes so that a narrow ruling class could rapidly join the life styles of Europeans and Americans, with whom they identified. ${ }^{9}$ Be that as it may, the results are clearer. In Brazil, for example, the development strategy focused on inviting foreign investors to produce consumer goods for its upper and middle classes. To be fair, savings rates in Brazil did improve and some heavy industry did take root, but nothing in comparison to countries like South Korea, and then Brazil was an exception in Latin America.

Neo-liberal scholars during the 1980s often blamed high tariffs in countries like Brazil as responsible for their lack of export prowess and debt crisis. This was discussed above. What is often forgotten is the important role high tariffs played in attracting foreign capital to Brazil and elsewhere in Latin America in the first place. Foreign investors came to Latin America, not to take advantage of their cheap labor for export promotion, but to take advantage of their protected elite markets. This is what Fishlow (1987) probably had in mind when he brilliantly characterized East Asian integration into the world economy as more along the axis of trade and Latin America's integration more along the axis of foreign capital; while countries like South Korea mobilized domestic resources and exported, Brazil

\footnotetext{
${ }^{9}$ It is difficult to support such a generalization with detailed case material in a short essay. For the important case of Brazil at least I developed such an argument in more detail elsewhere. See Kohli (2004), Chs. 4 and 5, esp. p. 182.
} 
and others invited foreign capital to produce for indigenous elites. The Latin American strategy worked as long as foreign capital kept coming in, and as long as a focus on enriching and catering industrialization to narrow elite tastes could be maintained politically, preconditions that have not always proven easy to sustain.

While there were many false starts, and a fair amount of learning occurred via trial and error, on the whole between 1950 and 1980, nationalist states consolidated power in most Asian countries, eliminating or mitigating the power of traditional intermediaries, minimizing the role of foreign capital, and laying the foundations for the development of indigenous technology and heavy industry. By contrast, the ruling elites in Latin America continued to rely heavily on foreign capital, failed to mitigate internal economic inequalities and the related elite-mass political gap, and constructed political economies that remained dependent on the outside world.

While the growth performance of many Latin American countries during this period was often impressive (again, notice Brazil), the fact is that this growth remained dependent on the availability of foreign capital. With growing foreign debt in the late 1970s and the early 1980s, foreign capital increasingly shied away from Latin America, leading to the "lost decade" of development. By contrast, most Asian economies surged ahead during the 1980s, especially the giants, China and India.

\section{ASIA VERSUS LATIN AMERICA, COPING WITH GLOBALIZATION}

On the whole, nationalist states of Asia have coped with globalization from a position of relative strength, making concessions when necessary, but also taking advantages of available opportunities. By contrast, indebted and dependent countries of Latin America have just as often confronted globalization on bended knees. When pressured by the U.S., the IMF, and the World Bank, Latin elites during the 1980 s and the 1990s readily embraced policies based on the "Washington Consensus" on development. The results include higher rates of economic growth and lower inequalities in much of Asia over the last three decades than in Latin America. With democracy, political reactions in Latin America only seem to confirm these tendencies: considerable political rage against the "Washington Consensus" on the one hand but an uneven political capacity to mobilize this anger constructively on the other hand. At one extreme we notice that the Mexican elites have narrowed their own political room to maneuver via NAFTA. At the other extreme, states in Brazil and Argentina have reasserted their economic presence and also focused on redistributive issues, especially in Brazil. In yet other cases, angry neo-populism has resurfaced, as in a Bolivia or a Venezuela. While inequality has come down in several Latin American countries, the basic growth pattern continues to be characterized by commodity exports and heavy dependence on foreign investment.

Select Asian economies - China, India, Vietnam, South Korea - are now among the world's fastest growers. While the respective developmental approaches of these countries differ, they also share some commonalities, especially when 
juxtaposed to some typical tendencies in Latin America. China, for example, is undergoing a state controlled transition from socialism to capitalism. While the role of foreign investment in this transition seems very large indeed, several qualifications are necessary. First, as was clear above in Table 4, the accumulated stock of FDI in China is still relatively modest (some 10 percent of China's GDP in 2010, while that in Brazil is close to 22 percent, not to mention Chile's 67 percent). Second, timing and sequence matters; much of FDI in China has come in after the Chinese state was well consolidated, directing the process of economic modernization on its own terms. And finally, as already noted, anywhere from half to two thirds of the so-called foreign investment going into China originates in Hong Kong and Taiwan. This Diaspora investment is less foreign investment and more the revenge of the Chinese bourgeoisie that were once ousted by the communists, and who are now busy reestablishing a state-capital alliance that will manage the new, enlarged and powerful China in the future.

India's liberalizing reforms are partly real but partly a myth. Direct foreign investment remains relatively limited in India and very recently India has even limited the inflow of the more speculative types of portfolio investments. The main model of development in India is a close alliance between state and indigenous capitalism (Kohli, 2012). The Indian state has carefully calibrated external opening of the Indian economy, ensuring that indigenous capital does not bear the brunt of such an opening. The state-capital alliance has facilitated rapid growth and some reduction in poverty, but growing inequalities are also retarding the poverty alleviating impact of growth.

Besides the Giants, South Korea has of course been one of the world's fastest growing economies for a long time. The Asian financial crisis hit South Korea hard but what is remarkable is the relatively quick recovery of economic growth (MacIntyre et al., 2008). The basic model of development has undergone some important changes in South Korea, but these are most evident in the financial sector. The core state-chaebol alliance for exports and growth remains intact. What is also noteworthy is the progress towards social democracy that is evident in South Korea (and in Taiwan) since democratization (Wong, 2004). Democratic pressures from below are clearly more consequential in economies dominated by national than by foreign capital.

A nationalist state-capital alliance that presides over high economic growth rates and moderate inequalities is the main model of development in Asia. Of course, there are exceptions (Indonesia's recovery is slow, Malaysia is achieving good growth and distribution with heavy foreign investment, and Philippines and few other countries remain laggards) but, on the whole, Asian countries have pursued a nationalist capitalist model of development, and with considerable success.

By contrast, national political formations remain relatively weak in dependent Latin America, economic growth remains a function of availability of foreign capital, and inequalities are proving to be very stubborn, as is the elite-mass political gap. Take, once again, the important case of Brazil. On the whole, Brazil is a well governed country. However, development choices within it are highly constrained, 
constraints that reflect accumulation of past choices. The domestic rates of savings remain quite low (Table 2) and, though the debt burden has declined, debt service burden (as a percent of exports) remains very high (Table 3). Brazil thus needs continuous inflows of foreign capital, both as a source of foreign exchange and economic growth. Wary of scaring away such investors, even left-leaning leaders like Lula or Dilma have shied away from policies - whether redistributive or growth promoting - that might involve the state in deficit spending and be held responsible for reemergence of inflation. Modest economic growth has returned and inequalities have declined (Table 1). All this is for the good; however, dependence on commodity exports - often to China — and on foreign capital continues. Without a strong developmental state, for now economic growth remains a function of steady foreign investment inflows and buoyant commodity demand.

To conclude, I have argued in this paper that the more nationalist model of development pursued in Asia is proving superior to the more dependent model of development of Latin America. This bald argument requires numerous qualifications: Asia and Latin America are large continents, with enormous internal diversity; the case that states in Asia are more nationalistic and effective than in Latin America can be overstated; and emerging trends of growing inequalities and further global integration in the giants, India and China, may well make the near-future different than the recent past. In spite of these qualifications, if the sketchy empirical analysis developed above is persuasive, an important conclusion follows: nationalism and effective national states remain important economic resources in a globalized world. On the whole, the more nationalist version of the capitalist models of development seems to be serving the needs of the citizenry in those countries better by generating higher rates of economic growth and limiting the worst forms of inequality.

\section{REFERENCES}

Amann, Edmund and Werner Baer, "Economic Orthodoxy versus Social Development: The Dilemas Facing Brazil's Labour Government,” Oxford Development Studies, V. 34, No. 2, June 2006.

Amsden, Alice H. Asia's Next Giant: South Korea and Late Industrialization, Oxford University Press, New York, 1989.

Branstetter, Lee and Nicholas R. Lardy, "China's Embrace of Globalization,” in Laven Brandt and Thomas G. Rawski, eds., China’s Great Economic Transformation, Cambridge University Press, New York, 2008, pp. 633-82.

Bresser-Pereira, Luiz Carlos, “Structuralist Macroeconomics and the New Developmentalism,' available at www.bresserpereira.org.br/papers/2011/11.22.

Cardoso, Fernando Henrique and Enzo Faletto, Dependency and Development in Latin America, 1979.

Cardoso, Fernando Henrique, “Associated-dependent Development," in Alfred Stepan, ed., Authoritarian Brazil: Origins, Policies, and Future, Yale University Press, New Haven, 1973.

Chang, Ha-Joon, Kicking Away the Ladder: Development Strategy in Historical Perspective, Anthem Press, London, 2003.

Evans, Peter, "Class, State, and Dependence in East Asia: Some Lessons for Latin Americanists," in Fredrick C. Deyo, ed., The Political Economy of the New Asian Industrialism, Cornell University Press, Ithaca, 1986, pp. 203-26. 
Evans, Peter, Dependent Development: the Alliance of Multinational, State, and Local Capital, Princeton University Press, 1979.

Evans, Peter, Embedded Autonomy: States and Industrial Transformation, Princeton University Press, Princeton, NJ, 1995.

Firebaugh, Glen, "Growth Effects of Foreign and Direct Investment," American Journal of Sociology, 98, 192, 105-30.

Fishlow, Albert, "Some Reflections on Comparative Latin American Economic Performance and Policy," Wider Working Papers, 22, August 1987.

Fishlow, Albert, et al. eds., Rich and Poor Nations in the World Economy, McGraw Hill, New York, 1978.

Johnson, Chalmers, Peasant Nationalism and Communist Power: The Emergence of Revolutionary China, Stanford University Press, Stanford California, 1962.

Johnson, Chalmers, "Political Institutions and Economic Performance," in Fredric Deyo, ed., The Political Economy of the New Asian Industrialism, Cornell University Press, Ithaca, 1986.

Kohli, Atul, Poverty amid Plenty in the New India, Cambridge University Press, New York, 2012.

Kohli, Atul, State-Directed Development: Political Power and Industrialization in the Global Periphery, Cambridge University Press, New York, 2004.

Krieckhaus, Jonathan, Dictating Development: How Europe Shaped the Global Periphery, University of Pittsburgh Press, 2006.

MacIntyre, Andrew, et al. eds. Crisis as Catalyst: Asia's Dynamic Political Economy, Cornell University Press, Ithaca, NY, 2008.

Newcombe, Hanna, et al., “United Nations Voting," International Organization, V. 24, No. 2. (Winter, 1970), pp. 100-21.

Rodrik, Dani, ed., In Search of Prosperity: Analytic Narratives on Economic Growth, Princeton University Press, Princeton, 2003.

Rodrik, Dani, Globalization Paradox: Democracy and the Future of the World Economy, W.W. Norton, New York, 2011.

Sachs, Jeffrey, "External Debt and Macroeconomic Performance in Latin America and East Asia," Brookings Papers of Economic Activity, 2:1985, pp. 523-64.

Skidmore, Thomas, Politics in Brazil, 1930-1964: An Experiment in Democracy, Oxford University Press, 1967.

Solimano, Andres, Vanishing Growth in Latin America: the Late Twentieth Century Experience, Edward Elgar Publishing, 2006.

Stallings, Barbara ed., Global Change, Regional Response: The New International Context of Development, Cambridge University Press, 1995.

Stallings, Barbara and Wilson Peres, Growth Employment and Equity: The Impact of the Economic Reforms in Latin America and the Caribbean, Brookings Institution Press, Washington, D.C., 2000.

Stiglitz, Joseph, Globalization and Its Discontents, W.W. Norton, New York, 2003.

Stiglitz, Joseph and Narcis Serra eds., Washington Consensus Reconsidered: Toward a New Global Governance, Oxford University Press, NY, 2008.

Tai, Hung-Chao, Land Reform and Politics: A Comparative Analysis, University of California Press, 1974.

Wade, Robert, Governing the Market: Economic Theory and the Role of Government in East Asian Industrialization, Princeton University Press, Princeton, 1990.

Williamson, John, Latin American Adjustment: How Much has Happened?, Washington, Institute for International Economics, 1990.

Wong, Joseph, Healthy Democracies: Welfare Politics in Taiwan and South Korea, Cornell University Press, 2004.

World Bank, Economic Growth in the 1990s: Learning from a Decade of Reform, Washington, D.C., 2005.

World Bank, World Development Report, Oxford University Press, 1991. 